\title{
Instabil mellkas sérülés halasztott stabilizálása
}

\author{
Esetbemutatás
}

\author{
DR. ZOLTÁN GERGELY, DR. NÉMETH ATTILA, DR. FLÓRIS ISTVÁN, \\ DR. TÖRÖK KLÁRA
}

\section{ÖSSZEFOGLALÁS}

Közleményünkben az instabil mellkas sérültek kezelésének szemléletét, lehetséges ellátási stratégiáit, illetve a mútéti stabilizálás időzítésének fontosságát szeretnénk bemutatni egy eset bemutatásán keresztül. 45 éves férfibetegünk kerékpárral elesve sérült. Kivizsgálása során jobb oldali, részben ablakos sorozatbordatörés, minimális légmell, tüdőzúzódás igazolódott. Megfelelő konzervatív kezelés mellett a kezdeti jó általános állapotot klinikai és radiológiai állapotromlás követte, haemothorax miatt mellkasi drenázst végeztünk, később a beteg lázassá vált, pneumonia miatt kombinált antibiotikum kezelést alkalmaztunk. A beteg általános állapota ismét javuló tendenciát mutatott, előkészítést követően posterolateralis thoracotomiából a reziduális folyadékgyülemet, amely alvadékos vért és exsudatumot tartalmazott, evacuáltuk, illetve az V-VI-VII-es bordákat AO szögstabil lemezekkel rögzítettük. A mellkas stabilizálását követően adekvát fájdalomcsillapítás és légzési fizioterápia mellett a beteg felépülése szövődménymentesen zajlott, teljes gyógyulását követően munkájához visszatért. A mellkasi sérültek ellátása során a terápia két alappillére az adekvát fájdalomcsillapítás és a korai, illetve késői szövődmények megelőzése kell, hogy legyen. A sérülés súlyosságától függően ez gyakran multidiszciplináris megközelítést kíván aneszteziológus és intenzív terápiás orvos, traumatológus, mellkas sebész, illetve gyógytornász bevonásával. A mellkasi sérülések jelentős százaléka konzervatív terápiával eredményesen kezelhető, azonban egyes esetekben a mútéti stabilizálás a teljes gyógyuláshoz elengedhetetlen. Amennyiben az indikáció fennáll, úgy a mútétet a lehető leghamarabb érdemes elvégezni, a mi betegünk esetében potenciálisan egy hosszú intenzív osztályos kezelést és több szövődményt megelőzhettünk volna egy korai stabilizálással.

\section{Kulcsszavak: $\quad$ Belsö rögzítés; Bordatörés; Mellkas sérülés; Lemezelés;}

\section{G. Zoltán, A. Németh, I. Flóris, K. Török: Delayed stabilization of flail chest-Case report}

Based on a case report, in our article we would like to discuss the most important aspects of the therapy of patients who suffered chest injury, the different treatment strategies and the importance of timing of surgical fixation of a flail chest. A 45 years old male fell with a bicycle in the mountains. He had stable cardio-respiratory parameters on admission, we diagnosed flail chest, multiple rib fractures on the right side, a small pneumothorax and pulmonary contusion. Despite of adequate conservative treatment at our intensive care unit, the patient's condition deteriorated both clinically and radiologically after the first few days. We inserted a chest tube because of haemothorax, and since the patient had fever, we started antibiotic therapy to treat his pneumonia. After the patient's general condition improved and the fever ceased, we performed a posterolateral thoracotomy, evacuated the residual fluid from the chest cavity and fixed the 5-6-7th ribs with angular stable AO plates. With adequate pain management and respiratory physiotherapy after surgery, the patient's healing process was rapid, thus he could leave the intensive care unit. We did not observe any further complications; he left the hospital and returned to his job soon after discharge. The cornerstones of the treatment of chest injured patients must be the appropriate pain management and prevention of both early and late complications. Depending on severity of the injury, this often needs a multidisciplinary approach with the involvement of intensive care specialists, anaesthesiologists, trauma surgeons, thoracic surgeons and physiotherapists. 
Although the majority of chest injured patients could be successfully treated with conservative methods, surgical fixation is necessary for a better outcome in some cases. If there is an indication for surgery, it is recommended to perform it as soon as possible; we could have possibly avoided a long intensive care unit stay and several complications in our case, such as pneumonia and recurrent haemothorax.

Keywords: $\quad$ Bone Plates; Flail chest - Diagnostic imaging/Surgery;

Fracture fixation, Internal - Methods; Rib fractures - Surgery;

Thoracic wall - Injuries/Surgery;

\section{BEVEZETÉS}

Az utóbbi évtizedekben az instabil mellkas sérültek mútéti stabilizálásának javallata változott, a mútéti beavatkozások aránya a konzervatív kezeléssel szemben csökkent $(8,9)$. Ez a tendencia több tényezőre vezethető vissza, amelyek között a korábbi mútétek relatíve magas szövődményrátája, illetve az intenzív terápia nagymérvű fejlődése mellett a megfelelő indikációs kritériumok hiánya is szerepet játszik. A súlyos mellkas sérültek sebészi kezelése határterületi kérdés, amennyiben mind mellkas sebész, mind traumatológus részvételére szükség lehet az ellátásban.

Közleményünkben egy esetbemutatás kapcsán kívánjuk felhívni a figyelmet a súlyos mellkas sérültek kezelésének alappilléreire, az ellátás során potenciálisan jelentkező szövődményekre és megelőzésükre, illetve a mútéti stabilizálás megfelelő indikációval történő alkalmazására és időzítésének fontosságára.

\section{ANYAG ÉS MÓDSZER}

45 éves, negatív anamnézisű férfibetegünk felvétele napján körülbelül $30 \mathrm{~km} / \mathrm{h}$-s sebességgel, kerékpárral elesve sérült. Mentőszolgálat szállította ambulanciánkra, gerincágyra fektetve, nyakcsigolya rögzítéssel, perifériás vénabiztosítással, $500 \mathrm{ml}$ krisztalloid infúzióval, stabil cardiorespiratoricus paraméterekkel (RR: 150/95 Hgmm, pulzus: 105/perc, O2 Sat.: $91 \%)$. Fizikális vizsgálat során mérsékelt dispnoe mellett, jobb oldalon dorsalisan gyengültebb légzési hangokat lehetett hallani, paradox légzést és subcutan emphysemát észleltünk. Kivizsgálása a nagy energiájú sérülésnek megfelelő protokoll szerint zajlott, röntgenfelvételek, hasi ultrahang vizsgálat készültek, laborvizsgálatokra mintát vettünk. A röntgenfelvételen észlelt jobb oldali III-X-es bordákat érintő sorozat, ablakos törések miatt (1. ábra) natív mellkas CT vizsgálatot végeztünk, amelyen minimális pneumothorax, basalis tüdőkontúzió és a IV. háti csigolya harántnyúlvány törése igazolódott (2. ábra). Intenzív osztályon kezdtük kezelését, kezdetben szisztémás, majd epidurális analgesiát alkalmazva a beteg a sérülést követő első 48 órában mindvégig jó általános állapotban volt, az intenzív osztályt elhagyhatta. Ezt követően a kontroll röntgen- és CT felvételeken a törések diszlokációját, a csontos mellkasváz deformitását észleltük, mellkasi folyadék jelent meg a sérült mellkasfélben (3. $a-b$ ábra). Haemothorax miatt mellüri drenázst végeztünk, kevéssel több, mint 1000 $\mathrm{ml}$ haemothoraxot távolítottunk el, és ismét intenzív osztályon folytattuk a kezelését. A következő két napban további $700 \mathrm{ml}$ ürült a mellkasi drénen keresztül. A sérülést követő 6 . napon a beteg lázassá vált, általános állapota rosszabbodott, az epidurális kanült és mellkascsövet eltávolítottuk, hemokultúrát vettünk, narkózisban bronchoszkópiát és lavage-t végeztünk, pneumonia klinikai és radiológiai képe miatt empirikus levofloxacin terápiát kezdtünk, amelyet a mikrobiológiai tenyésztés eredményének ismeretében (Staphylococcus aureus) célzottan folytattunk. Reziduális mellkasi folyadékgyülem miatt mellkaspunkció is történt. A kezelés hatására a beteg általános állapota javult (4. ábra), az intenzív osztályt elhagyhatta, ismétlődő láz miatt infektológus javaslatára kombinált antibiotikum terápiára (moxifloxacin, gentamicin, ceftriaxon) váltottunk. A beteg láztalanná vált. A mellkasfal restriktív deformitása, instabilitása miatt mellkasfali stabilizáló mútét mellett döntöttünk. Mútétre előkészítettük és a sérülést követő 26. napon sebész, mellkas sebész és traumatológus együttmúködésével posterolateralis thoracotomiából a reziduális folyadékgyülemet, amely alvadékos vért és 
exsudátumot tartalmazott, eltávolítottuk, az összenövések miatt dekortikálást végeztünk és az V., VI. és VII. csontos bordákat - az elhúzódó törésgyógyulás, a csontszélességet meghaladó diszlokációk és a restriktív mellkasfali deformitás miatt - a nagyobb stabilitást adó szögstabil AO lemezekkel fixáltuk (5. ábra). Mütét során négy egység vörösvértest koncentrátummal transzfundáltuk a beteget, posztoperatív megfigyelés és kezelés céljából további két napot intenzív osztályunkon töltött.

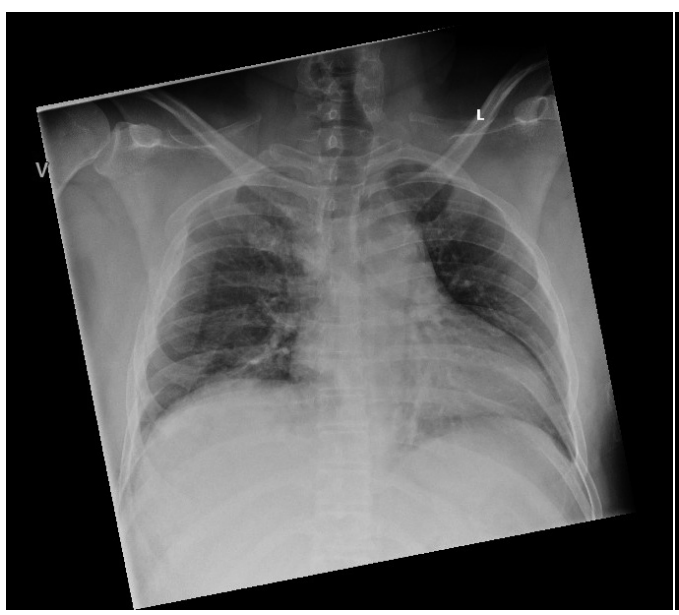

1. ábra

Jobb oldali III-X-es bordákat érintő sorozat, ablakos törések

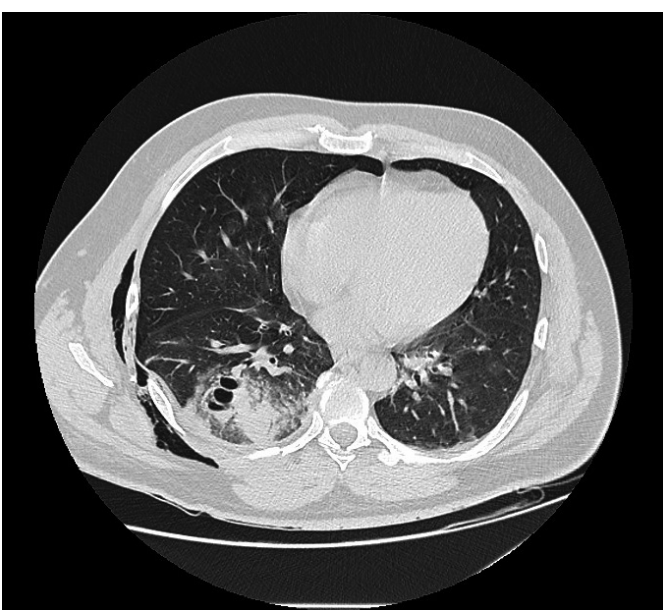

2. ábra

Nativ mellkas CT: minimális pneumothorax, basalis tüdőkontúzió és a IV. háti csigolya harántnyúlvány törése
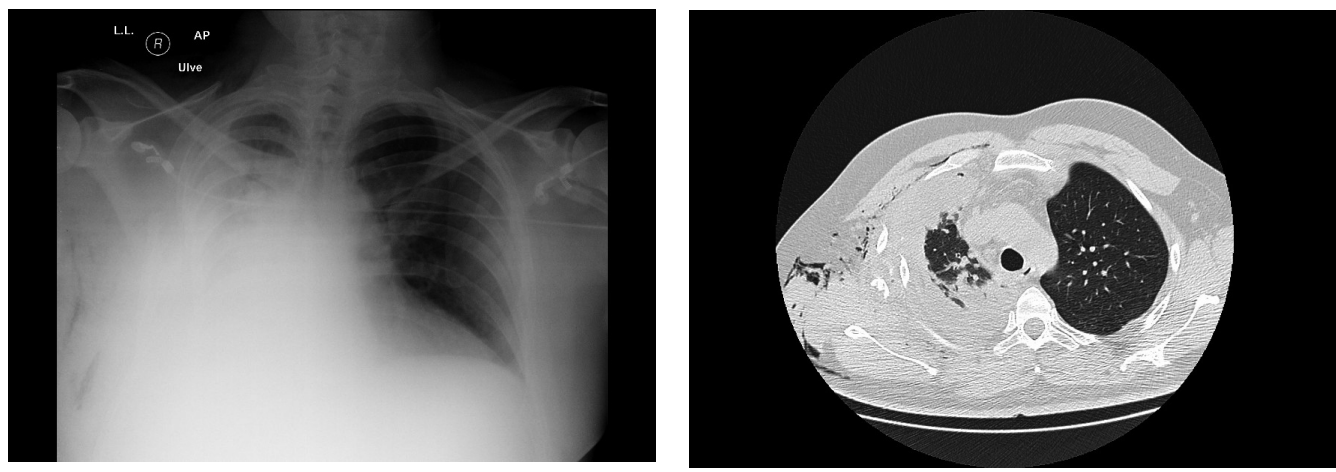

3. $a-b$ ábra

Kontroll röntgen- (a) és CT felvétel (b)

A törések diszlokációja, a csontos mellkasváz deformitása, mellkasi folyadék a sérült mellkasfélben 


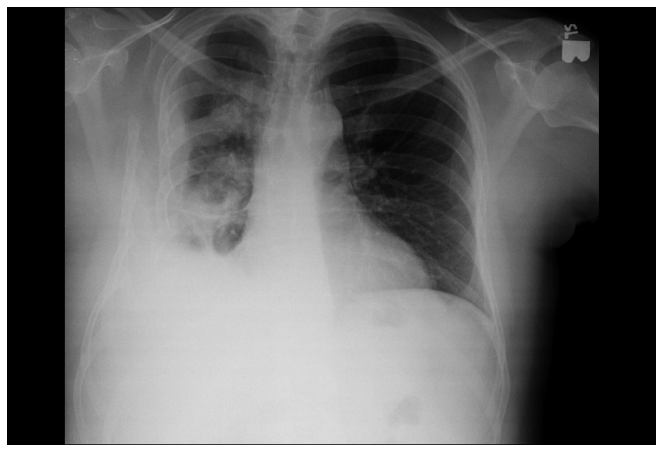

4. ábra

Mellkaspunkció utáni állapot

\section{EREDMÉNYEK}

A mútétet követően a beteg gyógyulása immáron szövődménymentesen zajlott, 10 nappal a mútét után jó általános állapotban hagyta el kórházunkat. A beteg összesen 36 napot töltött intézetünkben, ebből összesen 11 napot intenzív osztályon. Invazív beavatkozások közül kiemelendő a mellkasi drenázs, az epidurális kanül behelyezés, a két bronchoszkópia és egy mellkaspunkció, valamint a mútéti ellátás, a sérülés szövődményeként kialakult pneumonia miatt pedig hosszantartó kombinált

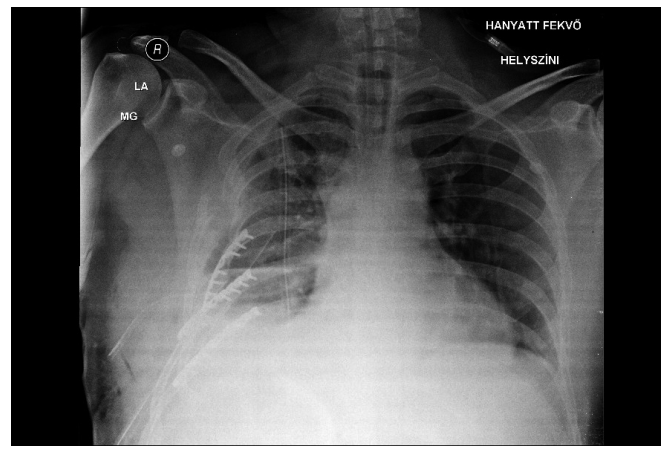

5. ábra

Szögstabil AO lemezes rögzítés

antibiotikum terápiát kellett végeznünk.

Betegünk az utókezelést követően mind munkájához, mind korábbi életmódjához viszszatért. A mútétet követően 6 hónappal a stabilizált csontos bordák konszolidációja mellett csak enyhe mellkasfali restrikció látható, de mellüregi szövődmény nem alakult ki (6. ábra). Az operációtól számított 6 . hónap végén légzésfunkciós vizsgálatot készítettünk (I. táblázat), amely enyhe fokú vitálkapacitás csökkenést és ugyancsak enyhe fokú obstruktív légzészavart igazolt.

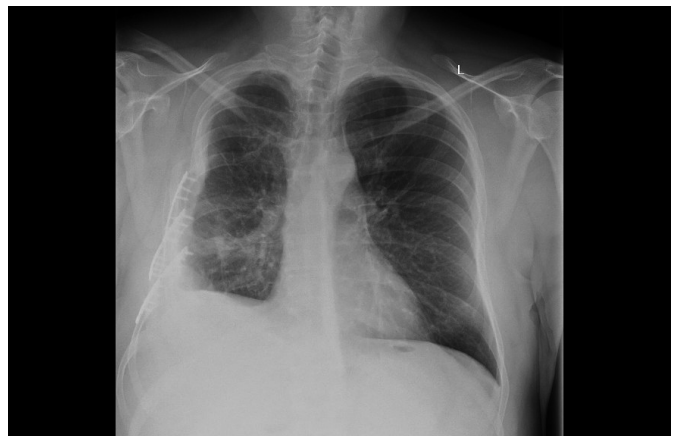

6. ábra

Mütét után 6 hónappal konszolidáció mellett enyhe mellkasfali restrikció látható, mellüregi szövődmény nélkül

I. táblázat Légzésfunkciós vizsgálat eredménye 6 hónappal a mütétet követően

\begin{tabular}{|c|c|c|c|}
\hline Paraméter & Mért érték & Referencia érték & $\%$ \\
\hline FVC [L] & 3.91 & 5.03 & 78 \\
\hline FEV1 [L] & 2.63 & 4.07 & 64 \\
\hline PEF [L/s] & 5.39 & 9.45 & 57 \\
\hline
\end{tabular}




\section{MEGBESZÉLÉS}

A mellkas sérültek terápiájában, legyen szó könnyű vagy súlyos sérültről, az aktuálisan észlelt állapot kezelése mellett legalább ugyanakkora hangsúlyt kell fektetni a rövid és hosszú távú szövődmények megelőzésére is. A kezelés során elsődleges az adekvát fájdalomcsillapítás alkalmazása, a haemo-, illetve pneumothorax drenázs, esetleges mútéti ellátása, bizonyos feltételek melletti szoros obszervációja, a megfelelő légzésfunkció biztosítása. Természetesen akár zárt, akár nyílt sérülés esetén a kísérő, akár életet veszélyeztető mellüregi, illetve egyéb sérülések sürgős, vagy halasztott sürgős ellátása kötelező. A kezelés gyakran kíván multidiszciplináris megközelítést, amikor traumatológus, mellkas sebész, aneszteziológus, intenzív terápiás orvos, radiológus, gyógytornász szoros együttmúködése szükséges a beteg gyógyulásához (4).

A csontos mellkasváz sebészi stabilizálása megfelelő kritériumok esetén önálló mútéti indikációt képezhet. Egy vagy két borda egyszerű törése a légzés mechanikáját általában nem rontja olyan mértékben, amelyet megfelelő fájdalomcsillapítással, illetve légzőtornával ne lehetne kompenzálni. Sorozat, illetve ablakos bordatörések azonban a mellkasfali restrikció miatt a légzésfunkciót olyan mértékben csökkenthetik, amely akár jelentős oxigenizációs zavarhoz, vagy más szövődmény kialakulásához vezethet $(5,6,10)$.

M. B. de Jong és munkatársai irodalomkutatást végeztek a bordatörések sebészi kezelésének stratégiájával kapcsolatban (2), WeiMing Wu és munkatársai pedig egy kontrollált randomizált vizsgálatot végeztek a többszörös bordatörések konzervatív és sebészi kezelésének összehasonlítására (12). Mindkét tanulmány vizsgálta a megfelelő indikációkat, illetve a rövid és hosszú távú eredményeket.

Sebészi stabilizálást követően szignifikánsan rövidült a mechanikus ventilláció időtartama, csökkent az intenzív osztályon, illetve a kórházban összesen eltöltött napok száma, a pneumonia incidenciája, a mortalitás és javult a páciensek szubjektív fájdalomérzete is (II. táblázat). Hosszú távon is kisebb fájdalomról számoltak be az operált betegek, ezen kívül szignifikáns csökkenés mutatkozott a mellkasfali feszülés mértékében, a nehézlégzés és a mellkasfali deformitás előfordulási rátájában is (III. táblázat). Az eredmények annál jobbak voltak, minél hamarabb sor került a mútéti rögzítésre. A mútéti indikációk a közlemények alapján a nemzetközi irodalomban sem teljesen egyértelmúek, az ajánlások a következőket veszik figyelembe: instabil szegmentum jelenléte, három vagy több borda törése, $50 \%$-nál nagyobb mértékű diszlokáció, súlyos mellkasfali deformitás, aktív, nagymértékű mellüregi vérzés, 45 évesnél idősebb életkor.

Az esetbemutatásunkban ismertetett betegünk 8 bordát érintő, részint ablakos töréseket szenvedett el, primeren is nagyfokú mellkasfali restriktív deformitással, a fenti tanulmányok ismeretében a stabilizálás mútéti indikációja egyértelmú volt. Egy korábban, legkésőbb a sérülést követő 1-2 napon belül elvégzett mútéttel potenciálisan egy hosszú intenzív osztályos és kórházi kezelés, valamint a fent ismertetett szövődmények elkerülhetőek lettek volna.

A nemzetközi ajánlások szerint az instabil szegmentummal járó ablakos bordatörések sebészi kezelése egyértelmű haszonnal, jobb eredményekkel jár, és bár az instabilitással nem járó, de sok bordát érintő és nagyobb deformitással járó törések rögzítésének szükségessége még vitatott, megfelelő indikációs kritériumok esetén a betegek ebből is mind rövid, mind hosszú távon profitálhatnának $(2,8,12)$.

A mellkasfali deformitás, illetve egyéb indikációk alapján végzett mellkasfali stabilizálásra az utóbbi években a nemzetközi irodalomban és a gyakorlatban is a szögstabil lemezrendszerek erre a régióra kifejlesztett implantátumait részesítik előnyben. Esetünkben is szögstabil lemezzel történt a rögzítés $(1,3,7)$.

Természetesen amennyiben a mútéti stabilizálás ismételten teret nyer a mellkasi sérültek ellátásában, ezzel az ellátó személyzetnek is lépést kell tartania. Magyarországon a traumatológus szakorvos képzés tartalmának a 90-es évek óta tartó folyamatos változása miatt, azt a kérdést, hogy az ilyen jellegű mútéteket traumatológus, vagy mellkas sebész végezze, két Szakmai Kollégium - évtizedes egyeztetés után a 2000-es évek elején - konszenzussal elfogadott alapelveiben határozták meg (11). Szabó és munkatársai munkája alapján a 90-es évek közepén a mellkasi sérültek körülbelül 4/5-ét kezelték traumatológiai osztályon és 1/5-ét mellkas sebészeti osztályon, ez az 
arány a 2000-es évek elejére tovább nőtt a baleseti sebészeti osztályok javára (9). Míg a mellkas sebészeti szakképzésben szerepel 3 hónap traumatológiai modul, addig a jelenlegi ortopéd-traumatológia közös képzésben sem a törzs- sem a szakképzési időszakban nincs mellkas sebészeti gyakorlat, tehát könnyedén előfordulhat olyan szituáció, hogy egy traumatológus szakorvos a pályafutása során nemhogy mellkas stabilizálásban nem asszisztál, de semmiféle mellkas sebészeti beavatkozásban sem. A mellkas sérültek traumatológiai ellátására feljogosító licenszvizsga lehetőséget teremt a traumatológusok számára a megfelelő jártasság megszerzésére, de ez a vizsga jelenleg teljesen opcionális a szakorvosok számára.

Tekintettel arra, hogy egy olyan sérülésfajtáról van szó, amely sok embert érint - és mind a rövid, mind a hosszú távú következmények életet veszélyeztetőek, illetve az életminőséget jelentősen befolyásolóak lehetnek - érdemes lenne a jövőben a hazai gyakorlatban is a konzervatív és a mútéti ellátások összehasonlítására prospektív klinikai vizsgálatokat végezni, megfelelő indikációs kritériumokat kidolgozni, valamint a mútéti stabilizálás személyi és tárgyi feltételeit biztosítani.

\section{II. táblázat Sebészi és konzervativ kezelést követő eredmények összehasonlítása}

(In: de Jong M. B. et al., 2014) (2)

The comparison of two groups of patients with acute phase of index

75 cases with surgical group and 89 cases with conservative group

\begin{tabular}{|c|c|c|c|}
\hline & Surgical & Conservative & P value \\
\hline MV time (day) & $3.7 \pm 1.4$ & $9.5 \pm 4.3$ & 0.037 \\
\hline ICU stay (day) & $8.2 \pm 4.3$ & $14.6 \pm 3.2$ & 0.041 \\
\hline Hospital stay (day) & $15.3 \pm 6.4$ & $26.5 \pm 6.9$ & 0.039 \\
\hline Tracheostomy (n) & 4 & 7 & NS \\
\hline Pneumonia (n) & $5(6.7 \%)$ & $17(19.1 \%)$ & 0.036 \\
\hline Mortality (n) & $1(1.3 \%)$ & $4(5.3 \%)$ & 0.045 \\
\hline
\end{tabular}

Acute indicators: 1 . The mechanical ventilation time and ICU stay days, 2 . The total hospitalization days, 3. The incidence of pneumonia, 4. The number of tracheotomy, 5. The number of mortality. (1. Lélegeztetett napok és intenzív osztályon töltött napok száma, 2. Összes kórházi tartózkodási idő 3. Tüdőgyulladás aránya, 4. Tracheostomiák aránya, 5. Halálozási arány)

\section{III. táblázat: Két betegcsoport krónikus indexeinek összehasonlítása}

(In: de Jong M. B. et al., 2014) (2)

\begin{tabular}{|c|c|c|c|}
\hline \multicolumn{4}{|c}{$\begin{array}{l}\text { The two groups of patients after the comparison of chronic index } \\
75 \text { cases with surgical group and } 89 \text { cases with conservative group }\end{array}$} \\
\hline & Surgical & Conservative & P value \\
\hline Thoracic pain & $2.9 \pm 1.2$ & $5.6 \pm 1.7$ & 0.043 \\
\hline Chest tightness & $10(13.3 \%)$ & $51(57.3 \%)$ & 0.014 \\
\hline Dyspnoe & $4(5.3 \%)$ & $20(22.4 \%)$ & 0.029 \\
\hline Chest wall deformity & $3(4.0 \%)$ & $72(93.5 \%)$ & 0.017 \\
\hline
\end{tabular}

Chronic indicators: 1. Chest pain condition, 2. Difficulty in breathing, 3. The chest wall tension, 4. Chest wall deformity. (1. Mellkasi fájdalom mértéke, 2. Légzési elégtelenség, 3. Mellkasfali tenzió, 4. Mellkasfali deformitás) 


\section{IRODALOM}

1. Bottlang M., Long W. B., Phelan D., Fielder D., Madey S. M.: Surgical stabilization of flail chest injuries with MatrixRIB implants: A prospective observational study. Injury, 2013. 44. (2): 232-238. https://doi.org/10.1016/i.injury.2012.08.011

2. de Jong M. B., Kokke M. C., Hietbrink F., Leenen L. P.: Surgical management of rib fractures: strategies and literature review. Scand. J. Surg. 2014. 103. (2): 120-125. https://doi.org/10.1177/1457496914531928

3. Engel C., Krieg J. C., Madey S. M., Long W. B., Bottlang M.: Operative chest wall fixation with osteosynthesis plates. J. Trauma, 2005. 58. (1): 181-186. https://doi.org/10.1097/01.TA.0000063612.25756.60

4. Molnár F. T.: Mellkasi trauma: ki, hogyan és mit? Magyar Sebészet, $2012 . \quad 65 . \quad$ (5): 355-361. https://doi.org/10.1556/MaSeb.65.2012.5.4

5. Molnar T. F.: Thoracic Trauma: Which chest tube when and where? Thorac. Surg. Clin. 2017. 27. (1): 13-23. https://doi.org/10.1016/j.thorsurg.2016.08.003

6. Molnar T. F.: Surgical management of chest wall trauma. Thorac. Surg. Clin. 2010. 20. (4): $475-485$. https://doi.org/10.1016/j.thorsurg.2010.07.004

7. Ng C. S., Ho A. M., Lau R. W., Wong R. H.: Chest wall reconstruction with MatrixRib system: avoiding pitfalls. Interact. Cardiovasc. Thorac. Surg. 2014. 18. (3): 402-403. https://doi.org/10.1093/icvts/ivt515

8. Paris F., Tarazona V., Blasco E., Cantó A., Casillas M., Pastor J., París M., Montero R.: Surgical stabilization of traumatic flail chest. Thorax, 1975. 30. (5): 521-527. https://doi.org/10.1136/thx.30.5.521

9. Szabó Gy. J., Renner A.: Mellkasi sérülések magyarországi ellátása traumatológiai osztályon. Magyar Traumatológia Ortopédia Kézsebészet Plasztikai Sebészet. 2013. 56. (2): 129-136.

10. Szabó Gy. J.: A mellkasfal mútéti stabilizálása. Medicina Thoracalis. 2003. 56: 43-45.

11. Szabó Gy. J.: Tájékoztató a biztonságosabb mellkas-sérült ellátás konszenzussal elfogadott alapfeltételeiről. Magyar Traumatológia Ortopédia Kézsebészet Plasztikai Sebészet, 2009. 52. (3): 286-290.

12. Wu W. M., Yang Y., Gao Z. L., Zhao T. C., He W. W.: Which is better to multiple rib fractures, surgical treatment or conservative treatment? Int. J. Clin. Exp. Med. 2015. 8. (5): 7930-7936.

\section{Levelező szerző:}

\section{Dr. Flóris István}

Péterfy Kórház-Rendelőintézet Országos Traumatológiai Intézet

E-mail: floris.istvan@obsi.hu 
